\title{
Pemodelan Dan Simulasi Cara Kerja Turbofan
}

\section{(Modelling And Simulation How The Turbofan Works)}

\author{
Nurcahyani Dewi Retnowati ${ }^{*}$, Dwi Nugraheny ${ }^{2}$, Heri Sunaryo ${ }^{3}$ \\ 1,2 Program Studi Informatika, Institut Teknologi Dirgantara Adisutjipto \\ E-mail: nurcahyanidr@itda.ac.id, henynug@gmail.com \\ ${ }^{3}$ Departemen Teknik Manajemen Industri, Akademi Angkatan Udara \\ E-mail: herisunaryo@aau.ac.id
}

\begin{abstract}
Modelling and simulation how the gas turbine works on a turbofan uses several processes, namely making modeling using Blender software and making animation simulations using Unity software. The method used is Multimedia Development Life Cycle (MDLC). In the turbofan, it can be seen that there is a change in air temperature pressure which is indicated by a change in color, sound and engine rotation. This simulation uses an ideal cycle of thrust force of 1 to 6 rpm, according to the state of the engine on the ground which is not affected by altitude, velocity and speed of sound. Based on the results of the functionality test, it is known that all the functions and buttons in the simulation can run well according to their functions and can be run on Windows 7, Windows 8, and Windows 10 operating systems.
\end{abstract}

Keywords—-Simulation, Turbofan, Engine, Multimedia Development Life Cycle

Abstrak-Pemodelan dan simulasi cara kerja gas turbin pada turbofan menggunakan beberapa proses yaitu pembuatan modeling dengan menggunakan software Blender dan pembuatan simulasi animasinya menggunakan software Unity. Metode yang digunakan adalah Multimedia Development Life Cycle (MDLC). Pada turbofan dapat diketahui adanya perubahan tekanan suhu udara yang ditunjukkan dengan adanya perubahan warna, suara dan perputaran mesin. Pada simulasi ini menggunakan siklus ideal gaya thrust sebesar 1 sampai 6 rpm, sesuai dengan keadaan engine yang berada di ground yang tidak terpengaruh oleh ketinggian, velocity dan kecepatan suara. Berdasarkan hasil dari uji fungsionalitas diketahui bahwa semua fungsi dan button yang ada pada simulasi dapat berjalan baik sesuai dengan fungsinya dan dapat dijalankan pada sistem operasi Windows 7, Windows 8, dan Windows 10.

Kata Kunci-Simulasi, Turbofan, Mesin, Multimedia Development Life Cycle

\section{Pendahuluan}

$\mathrm{E}$ ngine merupakan suatu bagian penting dari pesawat udara dan merupakan rangkaian komponen yang memanfaatkan gas untuk memutar turbin dengan pembakaran internal [1]. Komponen utama dari mesin turbin adalah inlet, kompresor, ruang bakar, turbin, dan nozzle adalah komponen utama dari mesin turbin gas [2]. Turbofan berbeda dengan mesin turbojet karena memiliki kipas tambahan di bagian depan pesawat yang dapat mempercepat aliran udara dalam saluran yang melewati mesin turbin gas inti [3].

\footnotetext{
*Penulis Korespondensi (Nurcahyani Dewi Retnowati)
}

E-mail: nurcahyanidr@itda.ac.id 
Oleh karena itu dilakukan pemodelan dan simulasi cara kerja turbofan dan proses yang terjadi, seperti perubahan suhu, perubahan warna, perputaran mesin, dan perubahan suara sehingga dapat memberikan manfaat kepada siapapun dalam memahami cara kerja turbofan. Pemodelan object menggunakan software Blender dan pembuatan simulasi dan animasi menggunakan software Unity.

\section{LANDASAN TEORI}

\section{A. Multimedia Development Life Cycle}

Multimedia Development Life Cycle (MDLC) digunakan dalam pembuatan pemodelan dan simulasi ini. Dalam metode MDLC terdapat beberapan tahapan yaitu concept, design, material collecting, assembly, testing, dan distribution. Pada tahap concept dilakukan identifikasi tujuan dan pengguna aplikasi, macam dan tujuan aplikasi. Tahap yang kedua adalah tahap design yang merupakan tahap untuk membuat spesifikasi mengenai arsitektur program dan tampilan. Tahap ketiga adalah material collecting dan merupakan tahap penngumpulan bahan sesuai kebutuhan yang akan dilakukan. Kemudian pada tahap keempat dilakukan assembly (semua bahan multimedia dibuat) dan setelah itu tahap testing yang merupakan pengujian dari aplikasi, serta tahap yang terakhir adalah tahap distribution (aplikasi disimpan dalam suatu media penyimpanan.[4].

\section{B. Software Blender}

Perangkat lunak atau software Blender merupakan software open source yang dapat digunakan dalam pembuatan object atau model tiga dimensi serta dapat langsung dalam pembuatan animasi [5]. Dengan software Blender juga dilakukan rendering dari object tersebut [6].

\section{Software Unity}

Perangkat lunak atau software Unity merupakan suatu software yang dapat digunakan sebagai game engine dengan logika script. Game engine dibangun dengan mengenkapsulasi beberapa fungsi standar misalnya rendering, pemanggilan suara, network, atau pembuatan partikel [7]. Dalam pembuatan simulasi juga membutuhkan assets yang diimport ke dalam software Unity.

\section{Simulasi}

Simulasi adalah suatu model yang dapat menunjukkan kondisi ataupun situasi untuk pembelajaran, tes, pelatihan, dan lain-lain. Simulasi tersebut juga menunjukkan deskripsi logis tentang bagaimana sistem bekerja atau komponen-komponennya bereaksi [8].

\section{E. Siklus Brayton}

Pada perekembangannya, siklus Brayton lebih diaplikasikan khusus ke mesin-mesin turbojet dan turbin gas. Siklus Brayton melibatkan tiga komponen utama yakni kompresor, ruang bakar (combustion chamber), dan turbin. Media kerja udara atmosfer masuk melalui sisi inlet kompresor, melewati ruang bakar, dan keluar kembali ke atmosfer setelah melewati turbin [9]. 


\section{METODOLOGI PENELITIAN}

\section{A. Multimedia Development Life Cycle}

Pembuatan pemodelan dan simulasi ini menggunakan metode Multimedia Development Life Cycle (MDLC) yang meliputi concept, design, material collecting, assembly, testing, dan distribution. Pada tahap concept, diidentifikasi pengguna dari simulasi ini adalah siapapun yang ingin mengetahui dan mempelajari tentang cara kerja dari turbofan dan tujuan simulasi ini adalah menjelaskan tentang cara kerja dari turbofan serta penjelasan proses yang ada di dalam turbofan ketika ada inputan kecepatan angin.

Pada tahap design dilakukan penentuan spesifikasi hardware dan software serta tampilan pada simulasi ini baik itu tampilan pada halaman utama maupun tampilan pada inputan kecepatan angin. Sedangkan pada tahap material collecting dilakukan pengumpulan bahanbahan materi yang mendukung dalam pembuatan pemodelan dan simulasi ini seperti bagaimana bentuk dari turbofan, kecepatan angin, cara kerja dari turbofan, dan lain sebagainya. Setelah itu akan masuk pada tahap assembly yaitu pemodelan dengan menggunakan software Blender dan pembuatan simulasi animasinya menggunakan software Unity serta desain tampilannya mengikuti hasil pada tahap design.

Kemudian hasil dari assembly dilakukan testing atau pengujian baik itu uji fungsionalitas semua button pada tampilan dapat berjalan sesuai dengan yang diharapkan atau tidak, dan apakah simulasi ini dapat menunjukkan cara kerja dari turbofan atau tidak, serta uji pada sistem operasi tertentu. Semua hasil assembly dan testing kemudian disimpan dalam harddisk internal, hal itu merupakan tahap terakhir dari metode MDLC yaitu distribution.

\section{B. Flowchart Pemodelan dan Simulasi}

Flowchart pemodelan pada turbofan dapat dilihat pada Gambar 1. Pada flowchart tersebut dilakukan pemodelan objek dasar sampai dengan tahap texturing dengan menggunakan software Blender Kemudian semua assets yang dibutuhkan dalam pembuatan simulasi ini diimport ke dalam software Unity dan diatur sesuai dengan perancangan tampilan simulasi. Setiap button pada tampilan diberikan fungsi logika dengan memberikan kode program agar simulasi dapat dijalankan. Setelah itu masuk ke tahap pengujian dimana simulasi ini akan diujikan fungsionalitasnya. Fungsi uji simulasi ini untuk mengetahui apakah fungsi-fungsi yang ada pada simulasi ini berjalan dengan baik atau tidak, dan juga mencari bug pada aplikasi ini. 


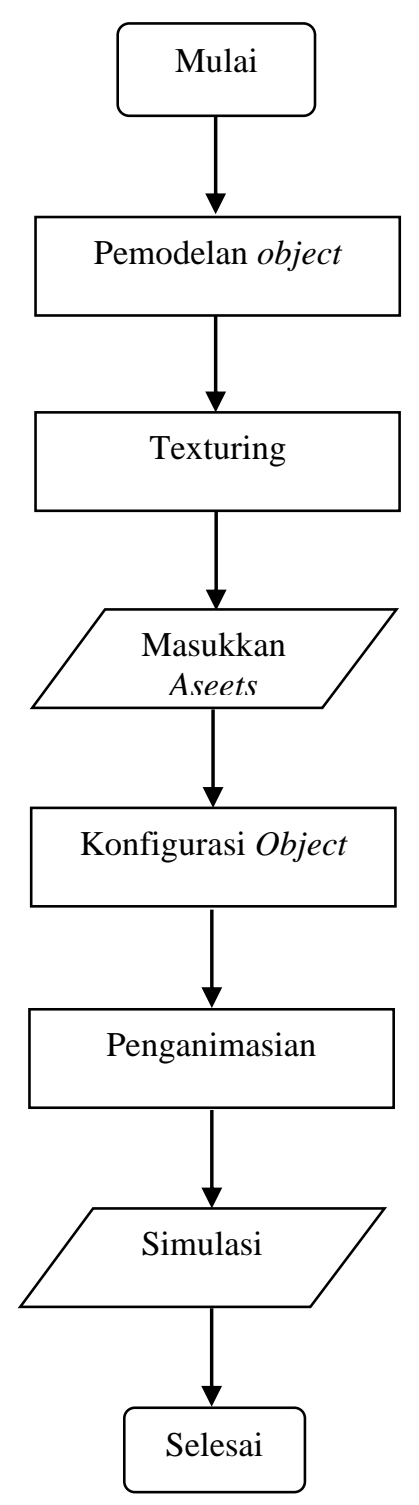

Gambar 1. Flowchart Pemodelan Turbofan

\section{Pemodelan dan Simulasi}

Pemodelan pada simulasi tiga dimensi ini terdiri dari dua hal yaitu modelling dan animation. Penjelasan dalam pembuatan turbofan dan komponen turbofan dijelaskan dalam modelling. Dengan modelling akan dijelaskan langkah-langkah dalam pembuatan objek 3D turbofan. Dalam bagian animation akan menjelaskan bagaimana objek di turbofan bergerak, bersuara dan terjadinya perubahan warna pada turbofan. Pemodelan menggunakan software Blender dan disesuaikan dengan blueprint dari turbofan. Pemodelan object (seperti pada Gambar 2) dilakukan hingga sampai tahap texturing atau pemberian warna. 


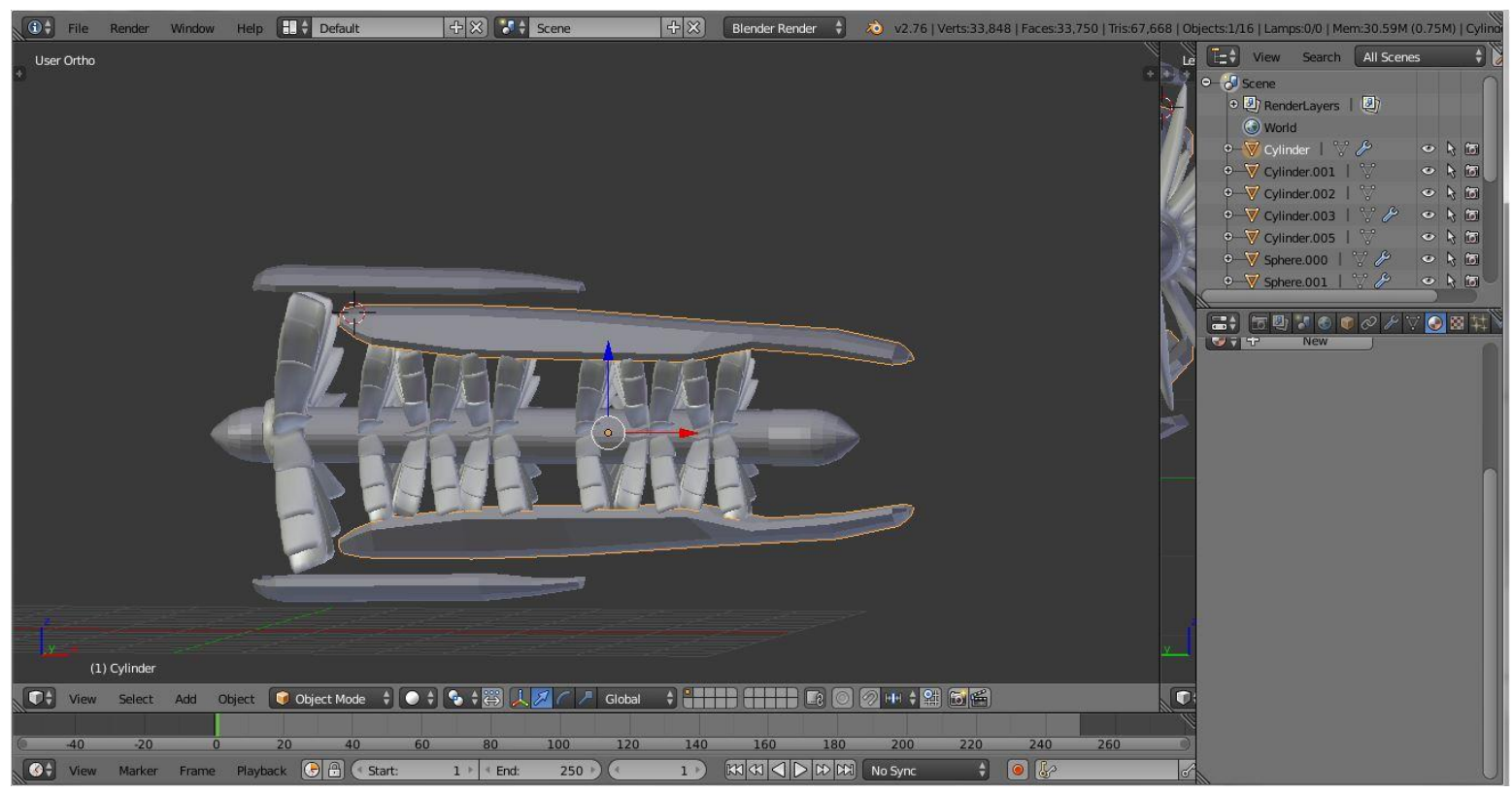

Gambar 2. Pemodelan Turbofan

Setelah tahap pemodelan selesai, dilakukan tahap simulasi dan animasi yang menggunakan software Unity. Tahap tersebut meliputi perancangan tampilan simulasi, memasukkan semua assets, dan penganimasian dari turbofan. Assets yang dimasukkan adalah semua komponen yang ada pada turbofan. Siklus yang digunakan pada proses yang terjadi di dalam turbofan menggunakan siklus Brayton.

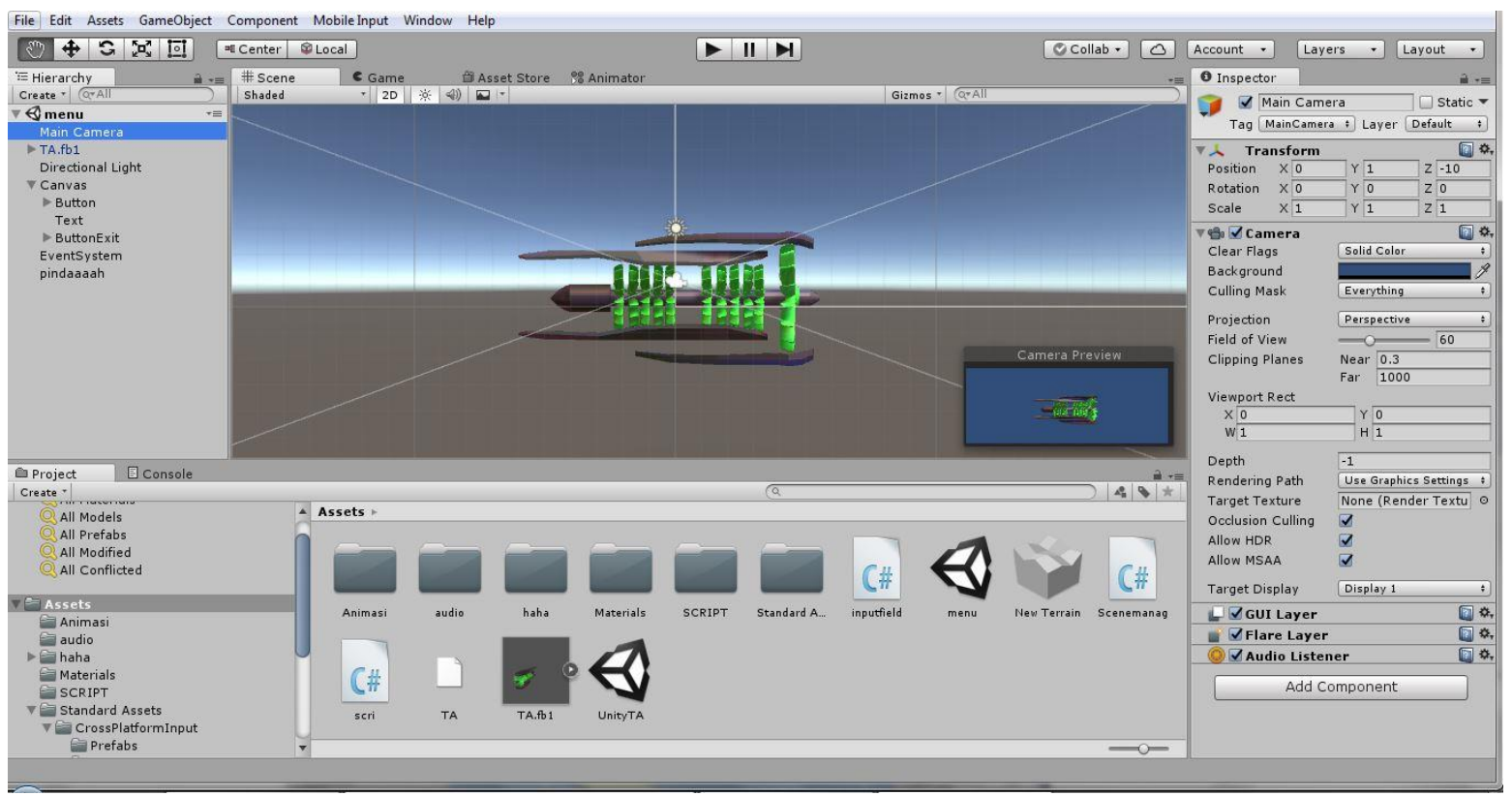

Gambar 3. Assets Object Turbofan

Pada Gambar 3 merupakan assets Turbofan yang telah dibuat dan di export ke dalam format .fbx di import ke dalam project game untuk di implementasikan pada simulasi.

Cara kerja turbofan ditunjukkan dengan adanya perubahan warna suhu udara pada turbofan 
yang dimana semakin tinggi kecepatan angin maka perubahan warna merah semakin merah, dan perubahan suara pada saat mesin turbofan dimasukkan kecepatan angin turbofan yang dimana semakin tinggi kecepatan angin maka perubahan suara semakin membesar. Perubahan warna dan perubahan suara seperti terlihat pada Tabel I.

\section{TABEL I}

DAFTAR PERUBAHAN WARNA DAN PERUBAHAN SUARA PADA CARA KERJA TURBOFAN [2]

\begin{tabular}{|l|c|c|}
\hline \hline Kecepatan Angin (rpm) & Warna & Suara \\
\hline Kecepatan angin 1 rpm & Merah Salmon Terang & $45.92 \mathrm{~dB}$ \\
\hline Kecepatan angin $2 \mathrm{rpm}$ & Merah Salmon Gelap & $55.19 \mathrm{~dB}$ \\
\hline Kecepatan angin 3 rpm & Merah Salmon & $76.82 \mathrm{~dB}$ \\
\hline Kecepatan angin 4 rpm & Merah Indian & $85.10 \mathrm{~dB}$ \\
\hline Kecepatan angin 5 rpm & Merah Bata & $93.79 \mathrm{~dB}$ \\
\hline Kecepatan angin 6 rpm & Merah & $110.04 \mathrm{~dB}$ \\
\hline \hline
\end{tabular}

\section{Perhitungan Gaya Thrust}

Pada simulasi ini menentukan kecepatan angin berdasarkan perhitungan gaya thrust, yang dimana rumusnya seperti pada Gambar 3.

$$
\frac{F}{m o}=\frac{a_{0}}{g c} * \frac{1}{1+\alpha}\left[\frac{v 9}{a_{0}}-M o+\alpha\left(\frac{v 19}{a_{0}}-M o\right)\right]
$$

\section{Gambar 3. Rumus Gaya Thrust Pada Pesawat}

Menentukan kecepatan angin dengan menggunakan F/mo 5930,794 yang dimana ada aturannya yaitu $a_{0}$ bernilai 457,0166, gc bernilai $1, \alpha$ bernilai 1 , Mo bernilai 1 , V9/a0 bernilai 12,9502 dan V19/a bernilai 0,048413. Sehingga kecepatan angin yang dimasukan dimulai dari 1 dan maksimal 6 jika lebih dari 6 maka simulasi berhenti atau tidak berjalan karena engine berada di ground maka kecepatan Mach Number(Mo) bernilai 1. Ini sesuai dengan keadaan engine yang berada di ground, yang tidak terpengaruh oleh ketinggian,velocity. Nilai F/mo $5930,794 \mathrm{lbf} /(\mathrm{lbm} / \mathrm{sec})$ sama dengan $6 \mathrm{rpm}, 1 \mathrm{lbf} /(\mathrm{lbm} / \mathrm{sec})$ sama dengan nilai $1 \mathrm{rpm}$. Pada simulasi ini inputannya menggunakan kecepatan angin karena kecepatan angin berhubungan dengan Mach Number sedangkan Mach Number untuk menentukan nilai thrust dan juga kecepatan masa aliran udara.

\section{IMPLEMENTASI DAN PEMBAHASAN}

\section{A. Tampilan Simulasi}

Implementasi merupakan pelaksanaan yang dijalankan untuk melaksanakan sebuah perancangan yang sudah dibuat secara tetap dan tidak ada perubahan didalamnya. Perancangan simulasi cara kerja turbofan ini diimplementasikan hanya pada platform desktop. 
Pada tampilan mulai aplikasi simulasi (seperti terlihat pada Gambar 4), jika pada di menu utama button start ditekan maka akan terdapat text berupa Kecepatan Angin (rpm), 1 text field untuk input kecepatan angin, 1 button play untuk memulai simulasi dan 1 button stop untuk menghentikan simulasi.

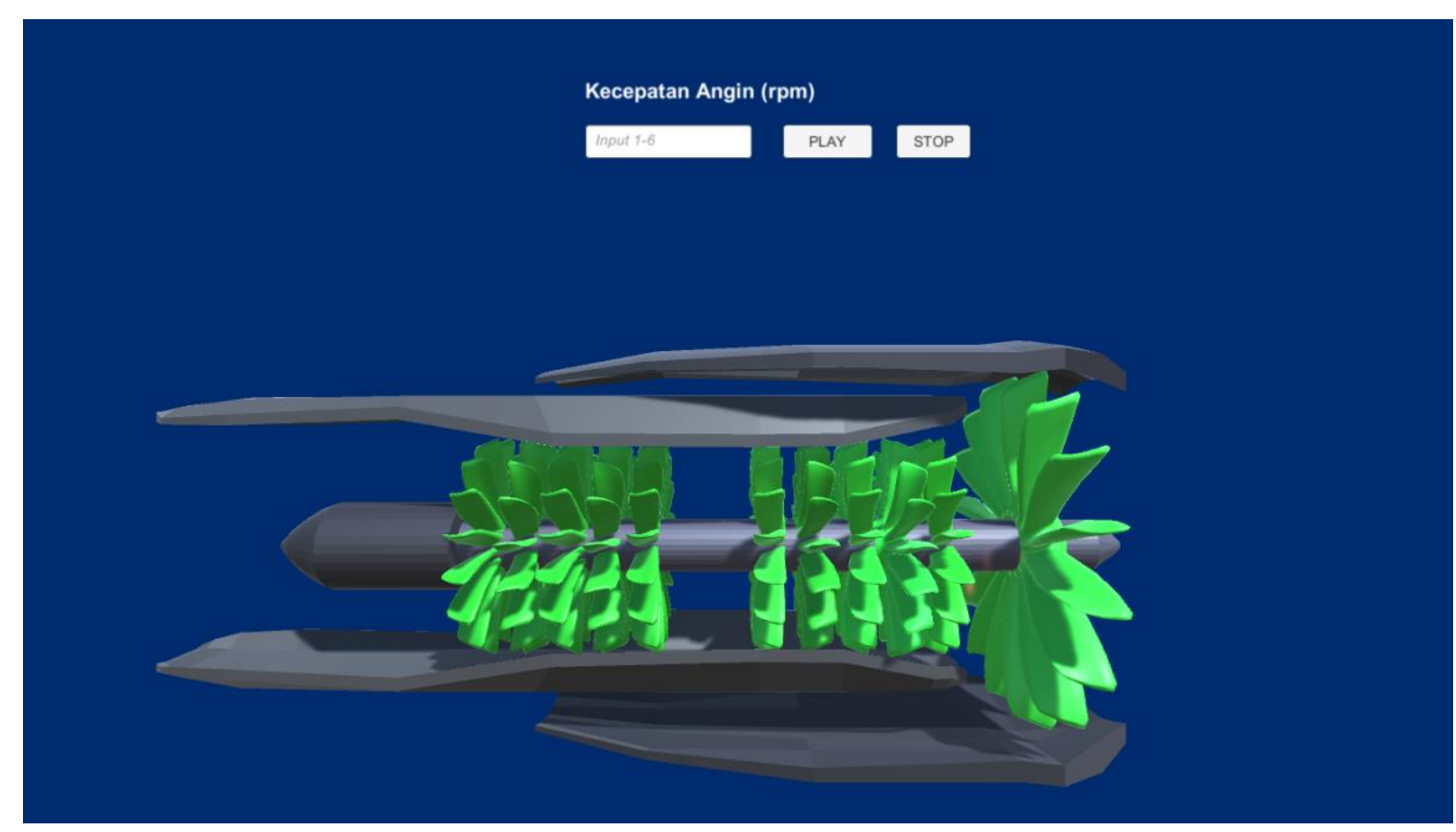

Gambar 4. Tampilan Mulai Aplikasi Simulasi

Jika diinputkan kecepatan angin sebesar $1 \mathrm{rpm}$ lalu tekan button play maka akan terjadi perubahan warna merah dan juga akan ada penjelasan tentang cara kerja turbofan di sebelah button stop (seperti terlihat pada Gambar 5). Begitu pula jika diinputkan kecepatan angin sebesar $2 \mathrm{rpm}, 3 \mathrm{rpm}, 4 \mathrm{rpm}, 5 \mathrm{rpm}$, dan $6 \mathrm{rpm}$ akan terlihat jelas perubahan warna yang terjadi. Semakin besar kecepatan angin yang diinputkan maka semakin besar pula perubahan suaranya, dan semakin cepat perputaran mesinnya, suhunya juga semakin meningkat. Selain itu juga pada simulasi juga muncul text box proses yang terjadi saat kecepatan angin diinputkan. 


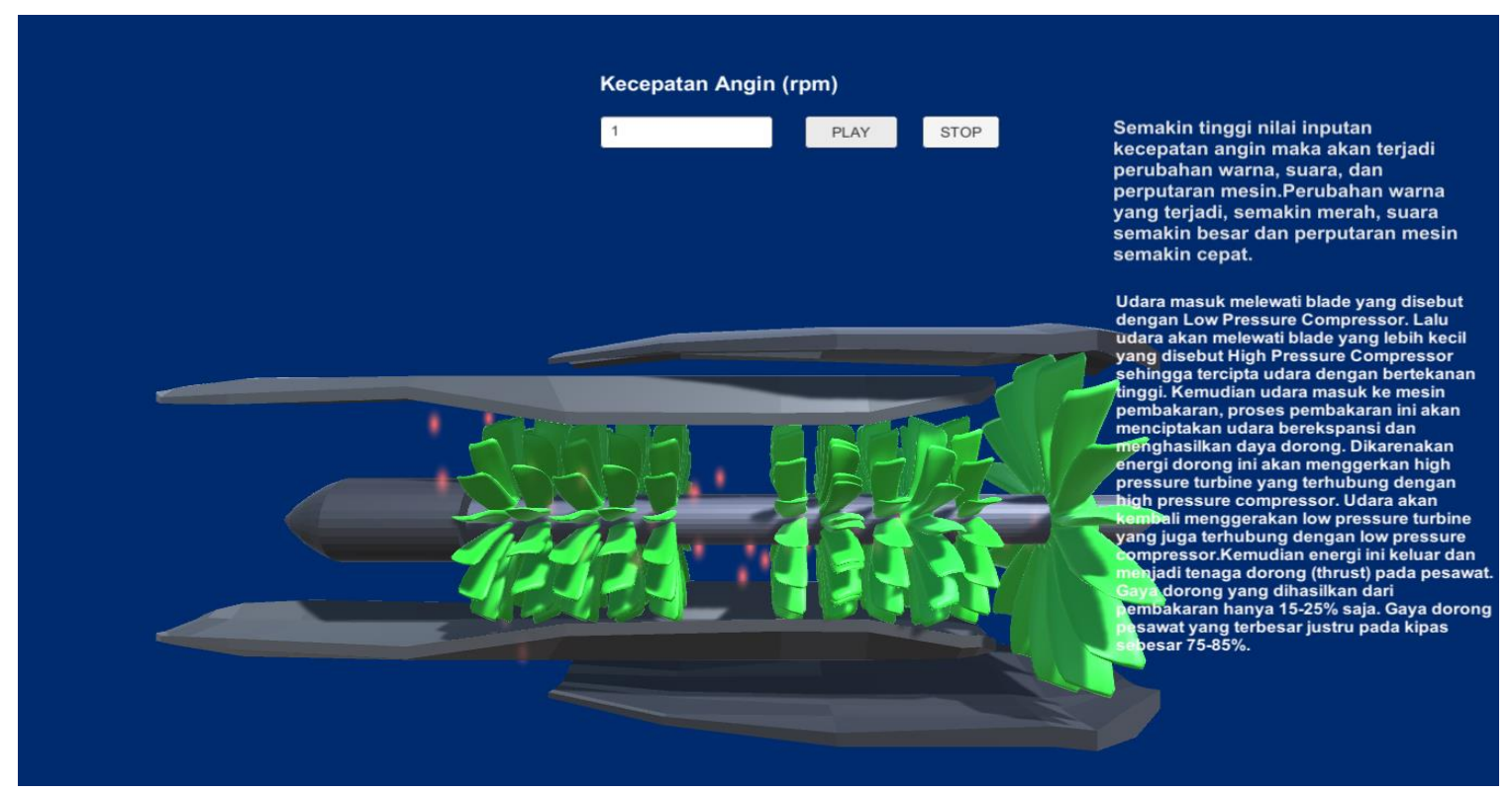

Gambar 5. Tampilan Saat Kecepatan Angin 1 rpm

Perubahan suhu, perputaran mesin dan perubahan suara tidak akan terjadi saat kecepatan angin yang diinputkan lebih dari $6 \mathrm{rpm}$, dan akan muncul notifikasi untuk menginputkan angka 1 sampai dengan $6 \mathrm{rpm}$.

\section{B. Pembahasan}

Uji fungsionalitas yang dilakukan pada simulasi ini meliputi uji fungsi apakah semua inputan pada kolom inputan kecepatan angin dan setiap button pada simulasi sesuai dengan yang diharapkan, serta uji yang menunjukkan apakah simulasi ini dapat berjalan dengan baik pada sistem operasi tertentu.

Hasil uji fungsionalitas tersebut menunjukkan button start dan button exit pada halaman menu utama, dan button play dan button stop pada halaman inputan kecepatan angin berjalan sesuai dengan yang diharapkan dan simulasi ini dapat dijalankan pada sistem operasi Window 7 , Windows 8, dan Windows 10. Dalam simulasi juga dapat menunjukkan semakin besar kecepatan angin yang diinputkan maka perubahan suku yang ditunjukkan dengan warna merah akan semakin meningkat, perputaran mesin semakin cepat, dan perubahan suara akan semakin besar pula. Hasil uji fungsionalitas seperti terlihat pada Tabel II. 
TABEL II

HASIL UJI FUNGSIONALITAS SIMULASI

\begin{tabular}{|c|c|c|c|}
\hline Kelas Uji & Skenario Uji & $\begin{array}{l}\text { Hasil Yang } \\
\text { Diharapkan }\end{array}$ & Hasil Yang Didapatkan \\
\hline Halaman Utama & Button Exit & $\begin{array}{l}\text { Keluar dari } \\
\text { tampilan simulasi }\end{array}$ & $\begin{array}{l}\text { Windows } 7, \text { Windows } 8 \\
\text { dan Windows } 10 \\
{[\sqrt{ }] \text { Berhasil }} \\
\text { [ ] Tidak berhasil }\end{array}$ \\
\hline Halaman Utama & Button Start & $\begin{array}{l}\text { Masuk ke tampilan } \\
\text { simulasi }\end{array}$ & $\begin{array}{l}\text { Windows } 7, \text { Windows } 8 \\
\text { dan Windows } 10 \\
{[\sqrt{ }] \text { Berhasil }} \\
{[] \text { Tidak berhasil }}\end{array}$ \\
\hline $\begin{array}{l}\text { Simulasi inputan } \\
\text { kecepatan angin } 1 \\
\text { s.d } 6 \mathrm{rpm}\end{array}$ & Button Play & $\begin{array}{l}\text { Simulasi dapat berjalan } \\
\text { dan menunjukkan } \\
\text { adanya perubahan } \\
\text { warna, perubahan suhu, } \\
\text { perputaran mesin, } \\
\text { perubahan suara }\end{array}$ & $\begin{array}{l}\text { Windows } 7, \text { Windows } 8 \\
\text { dan Windows } 10 \\
{[\sqrt{ }] \text { Berhasil }} \\
\text { [ ] Tidak berhasil }\end{array}$ \\
\hline $\begin{array}{l}\text { Simulasi inputan } \\
\text { kecepatan angin } 1 \\
\text { s.d } 6 \mathrm{rpm}\end{array}$ & Button Stop & $\begin{array}{l}\text { Simulasi berhenti dan } \\
\text { text penjelasan cara } \\
\text { kerja turbofan tidak } \\
\text { muncul juga. }\end{array}$ & $\begin{array}{l}\text { Windows } 7, \text { Windows } 8 \\
\text { dan Windows } 10 \\
{[\sqrt{ }] \text { Berhasil }} \\
\text { [ ] Tidak berhasil }\end{array}$ \\
\hline
\end{tabular}

\section{KESIMPULAN}

Kesimpulan yang dapat diambil adalah penelitian ini dapat mensimulasikan perubahan suhu, perputaran mesin, dan perubahan suara. Hasil uji fungsional menunjukkan bahwa simulasi ini dapat berjalan dengan baik pada sistem operasi Windows 7, Windows 8, dan Windows 10 dan semua fungsi pada simulasi dapat berjalan dengan baik, setiap text box untuk kecepatan angin dan setiap button pada user interface dapat berfungsi dengan baik.

Pengembangan penelitian ini diharapkan simulasi dapat dikembangkan dengan berbasis mobile dan website dan dapat lebih detail lagi dalam mensimulasikan cara kerja turbofan.

\section{UCAPAN TERIMA KASIH}

Ucapan terima kasih atas terbitnya naskah ini pada Seminar Nasional Sains Teknologi dan Inovasi Indonesia 2021 sebagai bagian kolaborasi/kerjasama penelitian antara Institut Teknologi Dirgantara Adisutjipto dengan Akademi Angkatan Udara.

\section{REFERENSI}

[1] Y. Gustiawan and B. P. Fitrikananda, "Kajian Low Oil Pressure pada Propeller Gearbox Engine CT7-9C Pesawat CN-235 PK-XNG dan Cara Penanggulangannya," J. Indept (Industri Elektro dan Penerbangan), vol. 4, no. 1, pp. 1-5, 2020.

[2] J. Mattingly, "Elements of Gas Turbine Propulsion," Tata McGraw-Hill, vol. 2005, pp. 
43-78, 1996.

[3] "Komponen mesin jet." [Online]. Available: https://id.hrvwiki.net/wiki/Jet_engine\#Turbofan.

[4] E. Rusnandi, H. Sujadi, and E. Fauzyah, "Implementasi Augmented Reality (AR) pada Pengembangan Media Pembelajaran Pemodelan Bangun Ruang 3D untuk Siswa Sekolah Dasar," Infotech J., vol. 1, no. 2, p. 236698, 2015.

[5] T. Mullen, T. Roosendaal, and B. Kurdali, [ Pdf ] Introducing Character Animation With Blender. Wiley India Pvt. Limited, 2007.

[6] S. V. Filippov, Blender software platform as an environment for modeling objects and processes of science disciplines, no. 230. 2018.

[7] R. Roedavan, Unity Tutorial Game Engine Edisi Revisi. Bandung: Penerbit Informatika, 2016.

[8] F. A. Ekoanindiyo, "Pemodelan Sistem Antrian Dengan Menggunakan Simulasi,” Din. Tek., vol. V, no. 1, pp. 72-85, 2011.

[9] A. Hafidz, "pemodelan siklus termodinamik turbin gas Rgtt kogenerasi," SIGMA Epsil. Bul. Ilm. Teknol. Keselam. Reakt. Nukl., vol. 15 (2), 2011. 